American Journal of Environmental Sciences 5 (3): 247-255, 2009

ISSN 1553-345X

(C) 2009 Science Publications

\title{
Effect of the 2004 'Boxing Day' Tsunami on Water Properties and Currents in the Bay of Bengal
}

\author{
Naveendra Reddy, Than Aung and Awnesh Singh \\ Physics Division, University of the South Pacific, Laucala Campus, Suva, Fiji
}

\begin{abstract}
Problem statement: Variation of temperature, salinity and geostrophic current in the Bay of Bengal due to the 2004 Boxing Day tsunami was investigated in this project using ARGO float and absolute dynamic height topography data. This was done to determine the effect of the tsunami on the water properties in the bay. Approach: The study area was between latitudes $5^{\circ} \mathrm{N}$ and $25^{\circ} \mathrm{N}$ and longitudes $75^{\circ} \mathrm{E}$ and $100^{\circ} \mathrm{E}$. Data from November 2004 and January 2005 were analyzed. The drift velocity of the ARGO float (within the study area) at its parking depth was calculated and compared with the geostrophic current at this depth in order to determine the appropriate reference level (level of no motion) for the study area. Results: The geostrophic current, using the Helland-Hansen equation, requires a reference level, which was then used to calculate the surface geostrophic current using the absolute dynamic height obtained from satellite altimetry. The appropriate level of no motion in the Bay of Bengal region was found to be $1500 \mathrm{~m}$. As a result of the tsunami, the variation in sea surface temperature was around $2-3^{\circ} \mathrm{C}$ and the variation in salinity was around 2-3 psu in the region. Accordingly, the dynamic height increased to about 20-30 dym cm just after the tsunami and abruptly changed the geostrophic surface currents pattern in Bay of Bengal. A few days after the tsunami, the geostrophic surface currents returned to normal. Conclusions: The variation of temperature and salinity in the Bay are the major causes of changes in the dynamic height, which results in the variation of geostrophic currents.
\end{abstract}

Key words: Bay of bengal, tsunami, geostrophic current, helland-hansen equation

\section{INTRODUCTION}

An earthquake of magnitude 9.3 on the Richter scale occurred offshore in northwest Sumatra (epicenter $3.32^{\circ} \mathrm{N}, 95.85^{\circ} \mathrm{E}$ ) on 26 th December 2004. It generated a huge tsunami, which devastated the Andaman and Nicobar Islands, the east coast of India and south Kerala $^{[1]}$. The tsunami was tracked by the Jason altimetry satellite early morning around 0300 hours on the same day, 2 hours after the earthquake ${ }^{[2]}$. This was the strongest occurrence since satellite altimetry started in the early 1970s.

The measurement shows an initial dominant wavelength of about $500 \mathrm{~km}$, followed by significantly greater height variation in the Bay of Bengal compared with those observed in earlier cycles recorded 10-20 days before the event and afterwards shows a return to the undisturbed ocean. During the event, the position of the wave is consistent with shallow-water wave speed of about $200 \mathrm{~m} \mathrm{sec}^{-1}$ at approximately $4500 \mathrm{~m}$ depth. The wave would have travelled about $1500 \mathrm{~km}$ in the $2 \mathrm{~h}$ since the earthquake occurred off the coast of Sumatra ${ }^{[2]}$.

The study area: The Bay of Bengal is a northern extended arm of the Indian Ocean, which is located between latitudes 5 and $22^{\circ} \mathrm{N}$ and longitudes 75 and $100^{\circ} \mathrm{E}$ as shown in Fig. 1. It is bounded in the west by the east coasts of Sir Lanka and India, on the north by the deltaic region of the Ganges, Brahmaputra and Meghna River systems and on the east by the Myanmar peninsula, extending up to the Andaman-Nicobar ridges. The southern boundary of the Bay is approximately along the line drawn from Dondra Head in the south of Sir Lanka to the north tip of Sumatra ${ }^{[3]}$. The Bay occupies an area of about 2.2 million sq $\mathrm{km}$ and has an average depth of $2600 \mathrm{~m}$ with a maximum of $5258 \mathrm{~m}$. Bangladesh is situated at the head of the Bay of Bengal.

Physical properties of ocean water in the Bay of Bengal: The important physical properties affecting

Corresponding Author: Awnesh Singh, Physics Division, University of the South Pacific, Laucala Campus, Private Bag, Suva, Fiji Tel: 679-3232645 Fax: 679-3231511 
seawater density and which controls the dynamic behavior of the ocean are temperature and salinity. Density is indirectly observed in the ocean, that is, it is computed from the measurements of the temperature and salinity fields as a function of depth. Therefore knowing the density, it is possible to deduce the movement of seawater.

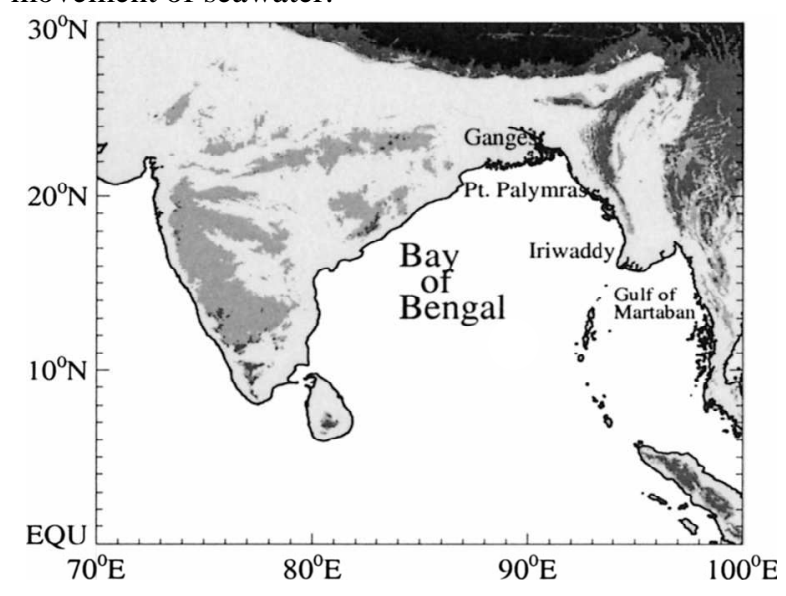

Fig. 1: Map of the Bay of Bengal

Temperature: In the Bay of Bengal, the thermocline is usually at a depth of $50 \mathrm{~m}$ and occasionally goes down $120 \mathrm{~m}$. Between February and March, the depth of the thermocline varied from 75-120 $\mathrm{m}$ in the western Bay and from 50-100 $\mathrm{m}$ in the eastern Bay. During the presummer season, a warm water cell is seen centered at $14^{\circ} \mathrm{N}, 85^{\circ} \mathrm{E}$ with a core temperature of $28^{\circ} \mathrm{C}$ at a depth of $100 \mathrm{~m}$. Two cold water cells are noticed towards the west $\left(18^{\circ} \mathrm{C}\right)$ and north $\left(17^{\circ} \mathrm{C}\right)$ of the warm water cell ${ }^{[4]}$. During the summer monsoon (monsoon is a wind pattern that reverses direction on a seasonal basis), a broad cold water $\left(20^{\circ} \mathrm{C}\right)$ band oriented in a southwestnortheast direction in the central Bay characterizes the temperature distribution at this depth. During the postsummer season, a warm pocket $\left(25^{\circ} \mathrm{C}\right)$ is located at $12^{\circ} \mathrm{N}, 83^{\circ} \mathrm{E}$, while during the winter monsoon, penetration of warm waters $\left(27^{\circ} \mathrm{C}\right)$ from the southeastern Bay towards the central Bay is seen ${ }^{[4]}$. Generally, examining the temperature, the thermocline is strong during the winter monsoon.

Salinity: Freshwater influx flows into the Bay of Bengal annually and about $50 \%$ of this comes during the summer monsoon months. During the summer monsoon, low saline water ( $29.0 \mathrm{psu})$ spreads into the interior of the Bay in a southwesterly direction from the head of the Bay and the northern Andaman Sea ${ }^{[4]}$, while during the winter monsoon, a large cell of low salinity water (34.9 psu) occupies the central Bay. At $500 \mathrm{~m}$ depth during the summer monsoon, the salinity distribution is characterized by zonal oriented isohalines with relatively high salinities in the central and southern Bay and low salinities north of $16^{\circ} \mathrm{N}$. At $1000 \mathrm{~m}$ depth during the summer season, lower salinities in the northwestern Bay and higher salinities off the southern east coast of India has been observed. But during the winter monsoon, along the $91^{\circ} \mathrm{E}$ meridional section of the longitude, two pockets of low salinity centered at 8 and $15^{\circ} \mathrm{N}$ are seen in the upper 50 $\mathrm{m}$. The halocline is located at about $75 \mathrm{~m}$ and a high salinity cell appears at depths of $90 \mathrm{~m}$ due to penetration of high salinity water ${ }^{[4]}$.

Density: The low salinity surface waters of the Bay of Bengal causes them in all seasons to be isolated from the deep waters by a sharp pycnocline between depths of 50 and $100 \mathrm{~m}$. The surface salinity variations within and between seasons are controlled by insulation, evaporative cooling and an influx of saline and freshwater. During the summer monsoon, the lowest density waters are seen in the north western Bay and the distribution pattern of density in this area resembles that of salinity. During the winter monsoon, surface water density is less than $1022 \mathrm{~kg} \mathrm{~m}^{-3}$. Two cells of very low density are found off the central east coast of India and northwest of the Andaman Islands, where freshwater discharges from the Krishna and Irrawady Rivers, respectively, enter the Bay ${ }^{[4]}$. Work has already been done on the entire oceans on geostrophic current using altimetry data and in the Indian Ocean ${ }^{[5-8]}$. During the 2004 tsunami, research on a satellite view of internal wave $^{[9]}$ found the effect of tsunami on marine ecosystem $^{[1]}$.

\section{MATERIALS AND METHODS}

Background theory of geostrophic current: The geostrophic ocean current at different layers is usually computed from the measured temperature and salinity profiles through the procedure called geostrophic method $^{[10]}$. The distribution of mass in the ocean is represented by the distribution of density. Density is computed from the measurements of temperature and salinity as a function of $\mathrm{depth}^{[11]}$. This computed density field could be thought of as creating gradients of pressure. The horizontal variation in the density field thus gives rise to the horizontal pressure gradient force. These horizontal pressure differences can be best represented by the parameter called dynamic height. Dynamic height represents the ability of a column of water to do work due to difference in geopotential- 
surface, where gravitational potential is constant. The geopotential height differences thus provide us with the reflection of pressure gradient force.

The geostrophic current is generated due to the balance between the Coriolis force and pressure gradient force and is expressed as shown in Eq. 1.

$$
\mathrm{V} .2 \Omega \sin \Phi=\frac{1}{\rho} \cdot \frac{\partial \mathrm{p}}{\partial \mathrm{x}}
$$

where:

$\mathrm{V}=$ Speed, $\Omega$ is angular speed of rotation of earth

$\Phi=$ Latitude

$\frac{\partial \mathrm{p}}{\partial \mathrm{x}}=$ the horizontal pressure gradient

The computation of the pressure gradient force requires at least a pair of stations and the geostrophic velocity calculation from the dynamic height difference between these stations is given by Eq. 2 .

$$
\mathrm{v}-\mathrm{v}_{\mathrm{r}}=\left.\frac{10\left(\Delta \mathrm{D}_{\mathrm{r}}-\Delta \mathrm{D}\right)}{2 \mathrm{~L} \Omega \sin \Phi}\right|_{\mathrm{A}} ^{\mathrm{B}}
$$

where:

$\mathrm{L}=$ Distance between two stations $\mathrm{A}$ and $\mathrm{B}$

$\Delta \mathrm{D}=$ Dynamic height anomaly at the surface

$\left(\mathrm{v}-\mathrm{v}_{\mathrm{r}}\right)=$ Geostrophic velocity normal to the line joining the two stations $\mathrm{A}$ and $\mathrm{B}^{[10]}$

As compared to other methods, this method has the advantage of not involving complex computations ${ }^{[12]}$.

The reference level (depth of no motion) plays an important part in calculating geostrophic current. The geostrophic calculation gives the relative velocity component $\left(\mathrm{v}-\mathrm{v}_{\mathrm{r}}\right)$ between two depths, therefore if we know the absolute value of either $\mathrm{v}$ or $\mathrm{v}_{\mathrm{r}}$, we will know the absolute value of the other. If direct current measurements are not available, the geopotential topography plots are usually based on some assumed reference level, generally in deep water. But there is one known velocity region which cannot be used as a reference level, that is, the sea bottom. The reason for this is that the velocity tends to be zero there because of the action of friction, a force which was deliberately assumed to be negligible when deriving the geostrophic equation $^{[10]}$.

Data acquisition: Two different sources have been used in this project to gather the datasets: the satellite altimetry dataset and the ARGO float dataset. The altimetry dataset is the primary source of information on ocean circulation variability and consists of maps of merged sea surface height anomalies and absolute dynamic height obtained from Topex-Poseidon and European Remote-Sensing Satellite (ERS-1 and ERS-2) missions ${ }^{[13]}$. The temperature and salinity data with depth from ARGO floats are available online ${ }^{[14]}$ and the absolute dynamic heights are also available online ${ }^{[15]}$. These are used to compute the geostrophic current in

\begin{tabular}{|c|c|}
\hline Specification & Details \\
\hline Selected float & 2900106 (WMO ID) \\
\hline Location & $\begin{array}{l}\text { Latitude range: } 13^{\circ} \mathrm{N}-14^{\circ} \mathrm{N} \text {; Longitude } \\
\text { range: } 82^{\circ} \mathrm{E}-84^{\circ} \mathrm{E}\end{array}$ \\
\hline Float type & Apex with SBE (Seabird) sensors \\
\hline Data period & 1st October 2004-28 ${ }^{\text {th }}$ February 2005 \\
\hline Float background & $\begin{array}{l}2900106 \text { is a profiling float deployed } \\
\text { under the US ARGO Project }\end{array}$ \\
\hline
\end{tabular}
the study area.

A particular Argo float was chosen as it had a relatively large cycle displacement, which enables for a better comparison of the calculated velocities for this study. The large displacements also ensure that the calculated geostrophic velocities are more likely to meet the Rossby radius requirement. Only one float was used for the estimation of the reference level in the study area, but three other floats were picked from close by for the temperature and salinity profile comparison. The reasons to select this particular ARGO float (specifications and details shown in Table 1) was that it is at the centre of the Bay and goes to the depth of $2000 \mathrm{~m}$.

The aim of satellite application is to obtain the dynamic height relative to a geoid ${ }^{[16]}$. The geoid is an equipotential surface on the Earth's gravity field that is closely associated with the location of the mean sea surface. The dynamic height data generated from the satellite were used in determining the geostrophic current and its variability in time and space. The altimetry dataset, used from AVISO (Archiving, Validation and Interpretation of Satellite Oceanographic data) in this study, consists of absolute dynamic height over the study area ranging from 5$25^{\circ} \mathrm{N}$ latitude and $75-100^{\circ} \mathrm{E}$ longitude, with a spatial resolution of $1 / 3^{\circ} \times 1 / 3^{\circ}$ from October 2004 to February 2005 .

\section{RESULTS AND DISCUSSION}

Temperature variations before and after the tsunami: The average temperature profiles from the different floats during November, December and January shows a significant decrease in sea surface temperature after the tsunami, as can be shown in Fig. 2a-d. The sea surface temperature before the 
tsunami was around $28^{\circ} \mathrm{C}$ whereas after the tsunami, the surface temperature decreased by $2-3^{\circ} \mathrm{C}$. The reason for this is because of the mixing and turbulence of surface water and cold bottom water.

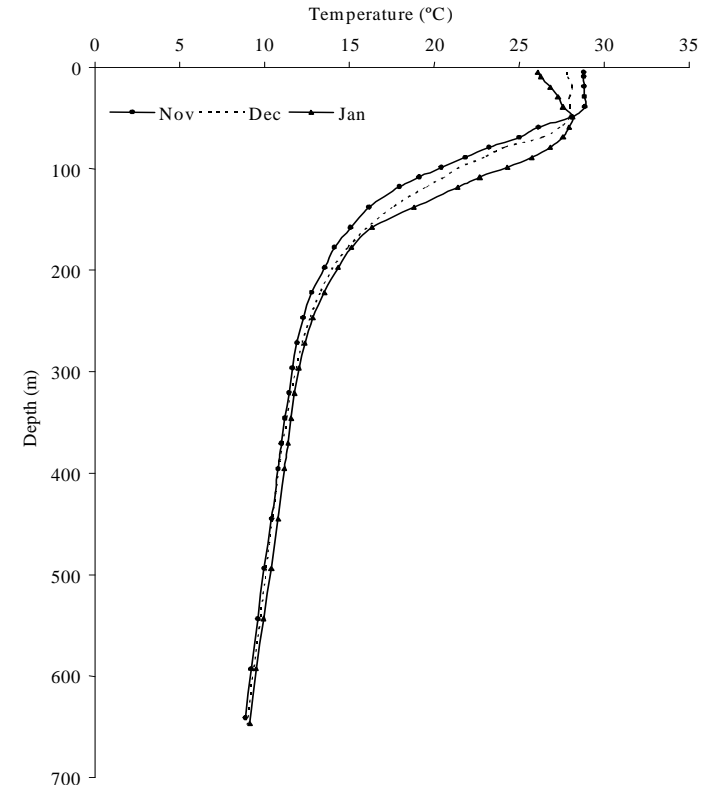

(a) Float 2900093

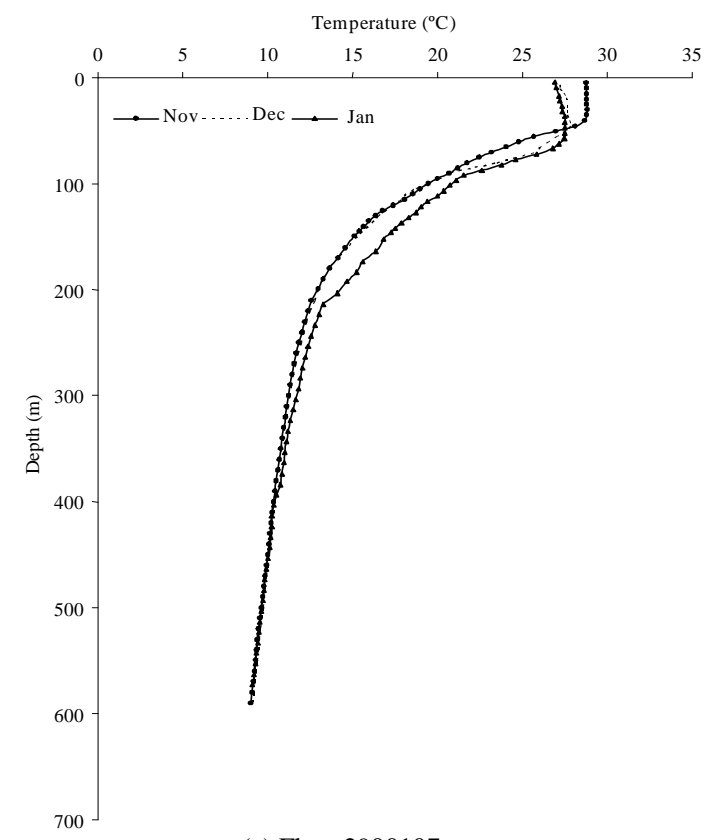

The temperature profile of floats 2900093 and 2900107, as shown in Fig. 2a and c, shows a steady decrease in the sea surface temperature during the months of November 2004 and January 2005,

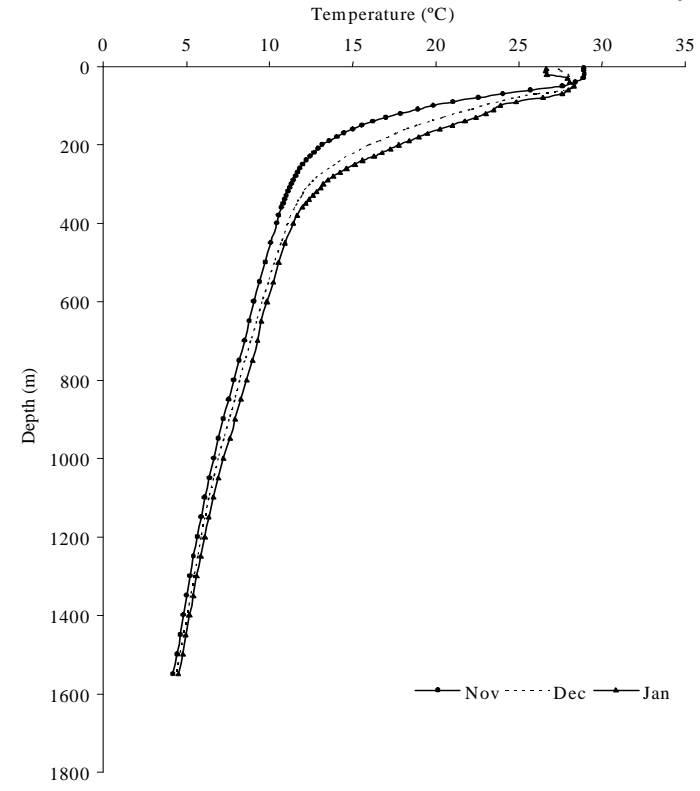

(b) Float 2900106

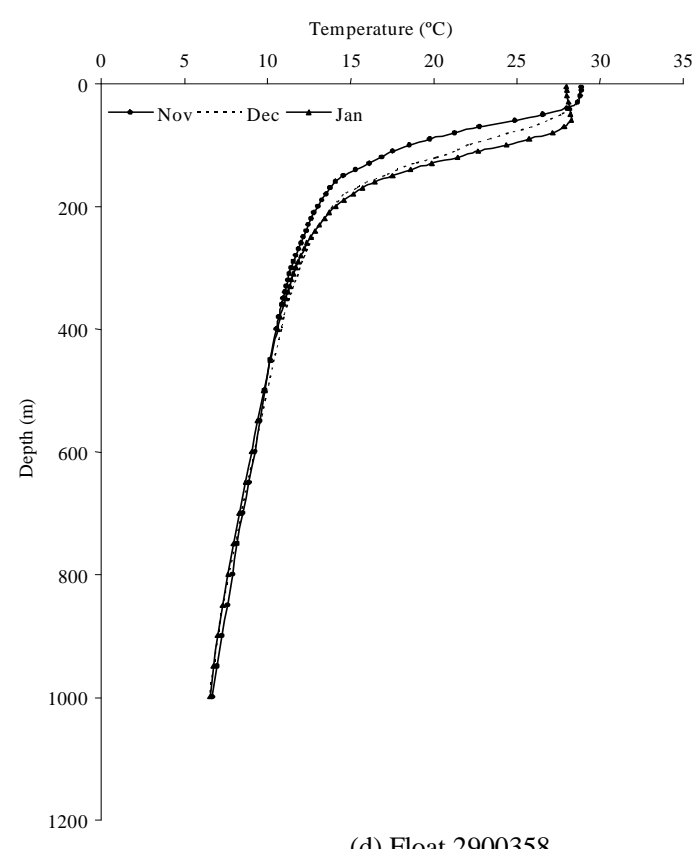

(d) Float 2900358

Fig. 2: Temperature profiles from different floats (a) 2900093, (b) 2900106, (c) 2900107 and (d) 2900358 during the period of November 2004 and January 2005

whereas the other two floats, 2900106 and 2900358, show little changes during these months, as can be shown in Fig $2 b$ and $d$. This is because of the location of the different floats in the Bay during the event. It is 
also to be noted that the northern hemisphere winter is between December and February.

Salinity variations before and after the tsunami: As temperature decreased after the tsunami, so did the

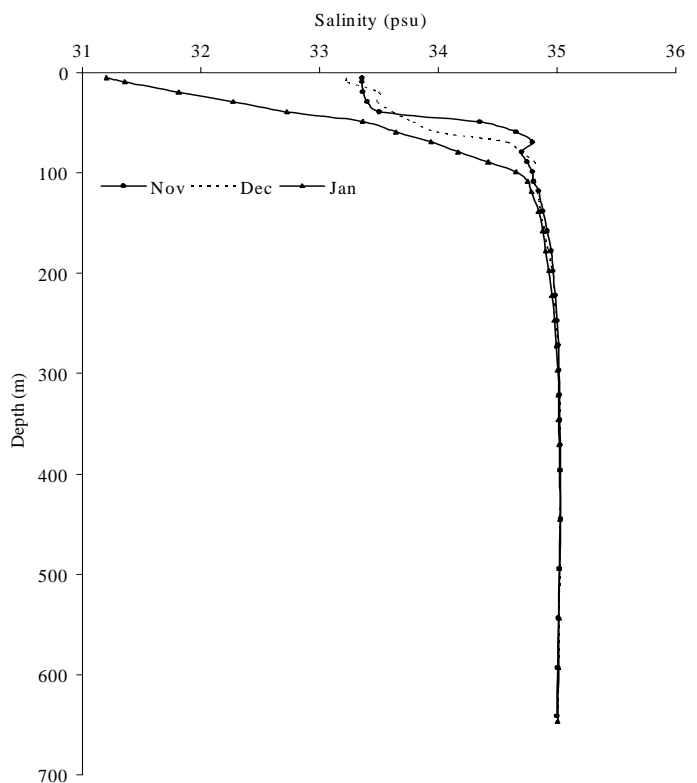

(a) Float 2900093

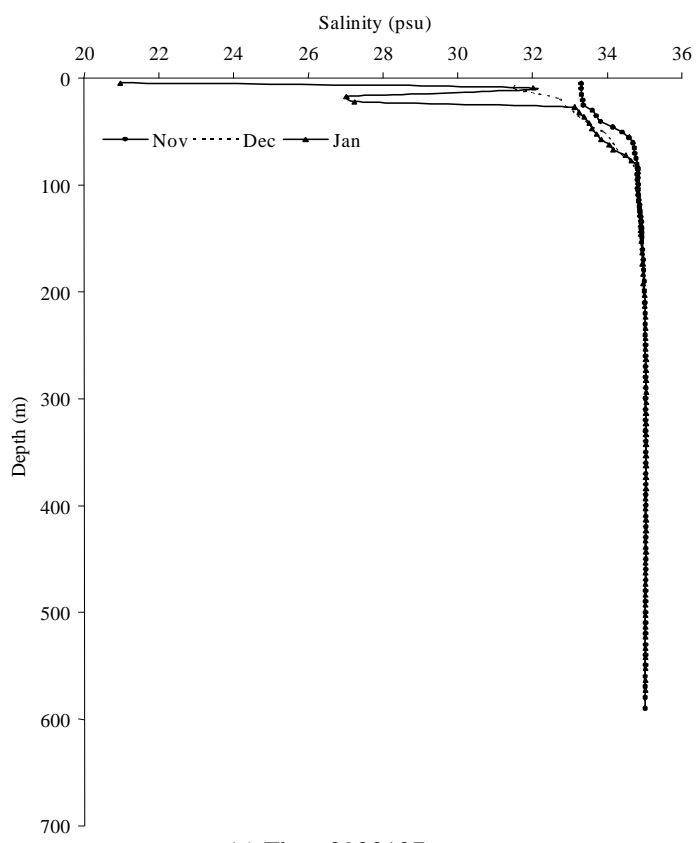

(c) Float 2900107 average salinity, as shown in Fig. 3a-d. During the tsunami, salt is left behind near the coastline allowing the salinity to decrease on the upper layer of the ocean. From the four floats selected, the ones which were near

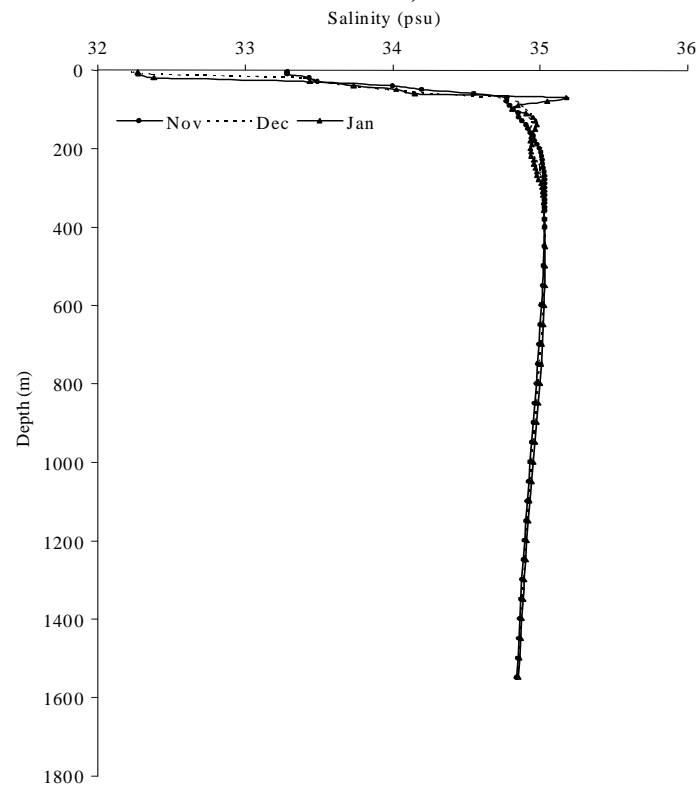

(b) Float 2900106

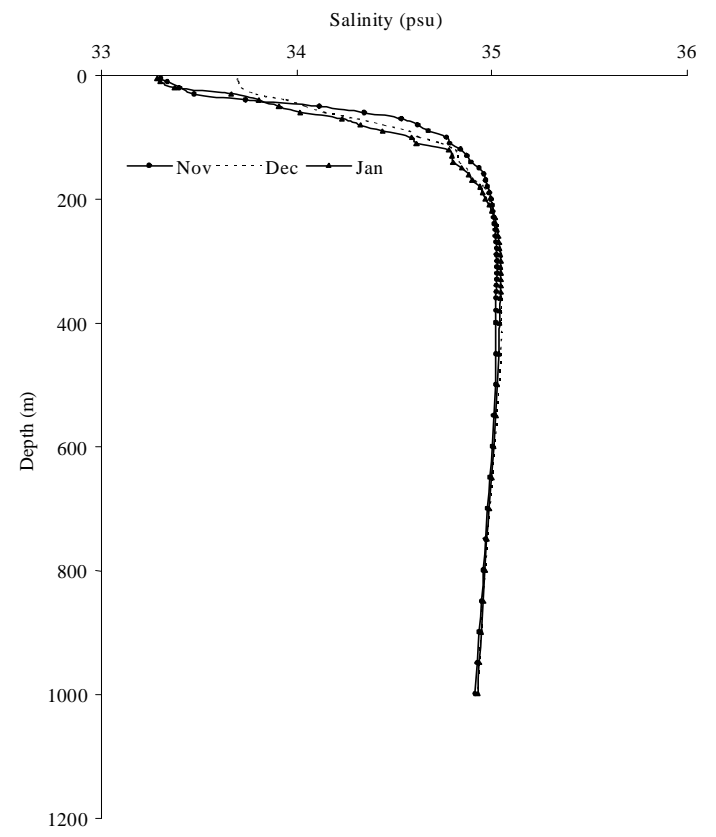

(d) Float 2900358

Fig. 3: Salinity profiles from different floats (a) 2900093, (b) 2900106, (c) 2900107 and (d) 2900358 during the period of November 2004 and January 2005. 
or close to the shore show little or a slight decrease in salinity. But for those floats that were at the centre or in the deep sea, an increase in the salinity was observed.

The loss in salinity has been gained by the vegetation near the coast or on land after the event. The results also depict that the salinity changes up to a depth of $100 \mathrm{~m}$ and then it was constant for the deeper part (Fig. 3a-d).

Drift velocity of ARGO float at its parking depth: The drift velocity of float 2900106 was calculated using estimated displacements calculated using a spreadsheet (latitude/longitude) distance calculator available online $^{[17]}$. The calculated displacement was then divided by the approximate time between two cycles, which was adjusted to account for the time required for the float to park, ascend and descend (that is, 10 hrs every cycle) at the parking depth of $1000 \mathrm{~m}$. There is some error present in estimating the drift velocities of the float at its parking depth. This error is due to drifting of the float at the surface before and after the position of the float is determined and can be evaluated if the time when ascent or decent begins, is known. This is because the satellite will not necessarily fly over a float immediately after it resurfaces or immediately before it descends due to the satellite's orbital frequency. Therefore, generally the drift velocity is overestimated by $25 \%$, which in other words, is the error in estimating drift velocity at this depth ${ }^{[18]}$.

Temperature and salinity from float 2900106 at $1000 \mathrm{~m}$ depth: From the cycle profile datasets (that is, cycles 1 - 15), the recorded temperature and salinity values at $1000 \mathrm{~m}$ depth have been plotted and are shown in Fig. 4a and b respectively. For comparison of the temperature and salinity effect on density, the density values have also been calculated and plotted and can be shown in Fig. 4c. The direct relationship between temperature, salinity and density variations are clearly shown.

Geostrophic current and drift velocity comparisons at $1000 \mathrm{~m}$ depth: The calculated geostrophic current at $1000 \mathrm{~m}$ depth, using only two stations, can result in under-estimation as only the velocity component at right angles to the two stations are determined. In order to improve this situation, three stations and vector summation are used to obtain a more realistic result ${ }^{[19]}$. After a number of attempts using different reference levels, such as 1200, 1500, 1800 and $2000 \mathrm{~m}$, it was finally determined that a reference level of $1500 \mathrm{~m}$ offers the best comparison results of the drift velocity of the float at its parking depth and calculated geostrophic current at the same depth using the ARGO, temperature and salinity dataset. Table 2 shows the input parameters and values of ARGO float 2900106 and Table 3 shows a summary of the geostrophic current and drift velocities of ARGO float 2900106 at its parking depth of $1000 \mathrm{~m}$.

Geostrophic current calculation using absolute dynamic height: The absolute dynamic height data gathered $^{[15]}$ was used to calculate the surface currents.

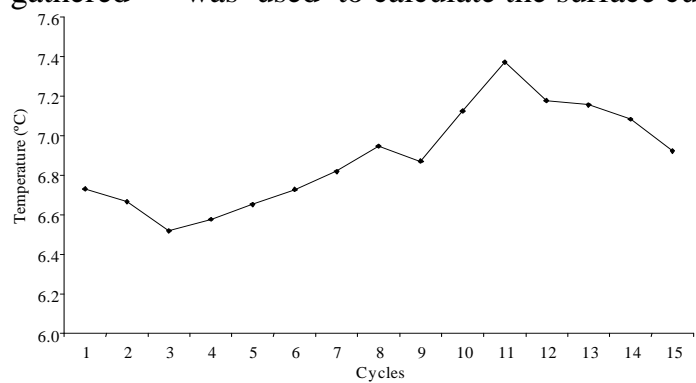

(a)

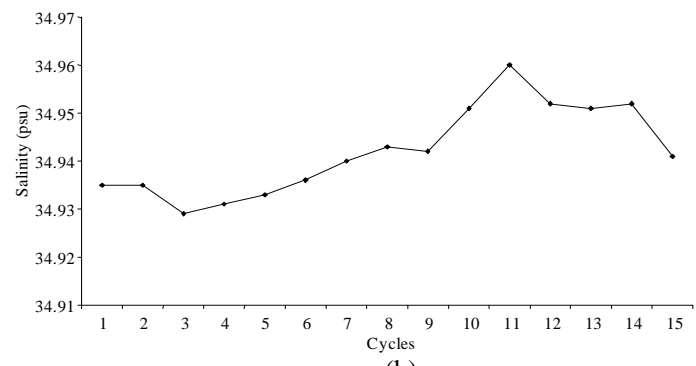

(b)

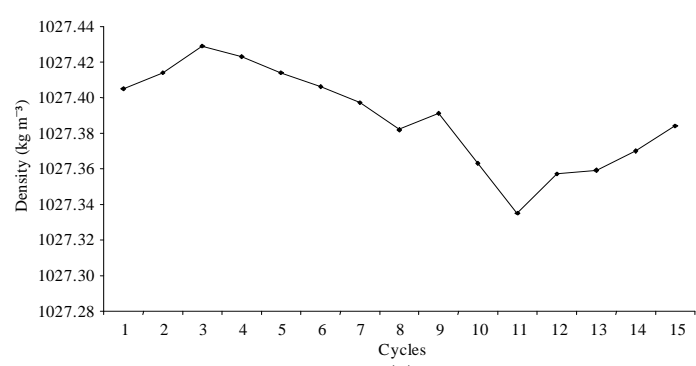

(c)

Fig. 4: The (a) temperature, (b) salinity and (c) calculated density values for each cycle at 1000 $\mathrm{m}$ depth from float 2900106

Table 2: Input parameters and values of ARGO float 2900106

\begin{tabular}{ll}
\hline Input parameters: & Input values \\
\hline Average latitude, $\Phi$ & $14.15^{\circ} \mathrm{N}$ \\
Depth, H & $2600 \mathrm{~m}$ \\
Reference level, $\mathrm{Z}_{0}$ & $1500 \mathrm{~m}$ \\
Coriolis parameter, $\mathrm{f}$ & $3.57 \times 10^{-5} \mathrm{rad} \mathrm{sec}^{-1}$ \\
\hline
\end{tabular}


Table 3: Summary of geostrophic current and drift velocities of ARGO float 2900106 at its parking depth of $1000 \mathrm{~m}$

\begin{tabular}{lcc}
\hline & Drift velocity $\left(\mathrm{cm} \mathrm{sec}^{-1}\right)$ & Geostrophic velocity $\left(\mathrm{cm} \mathrm{sec}^{-1}\right)$ \\
\hline Minimum & 5.10 & 5.90 \\
Maximum & 8.90 & 9.40 \\
Average & 7.02 & 7.47 \\
\hline
\end{tabular}

In this calculation, the reference level of $1500 \mathrm{~m}$ was used. The southern part of the Bay of Bengal lies near the equator thus while plotting surface geostrophic current vector plot, the study area was confined above $4^{\circ} \mathrm{N}$. This is because the equation becomes invalid near the equator, because the Coriolis force is zero at the equator.

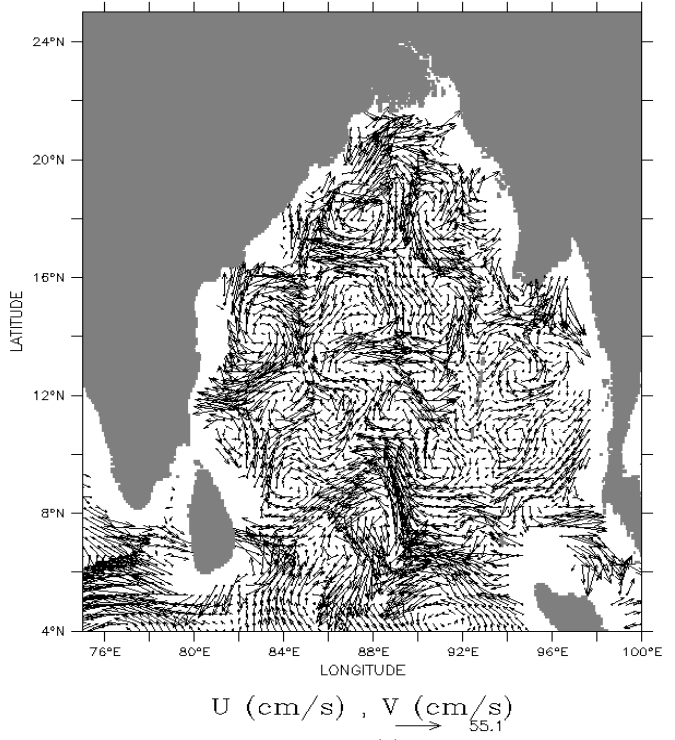

(a)
Surface current before and after the tsunami: The geostrophic surface current was around $45 \mathrm{~cm} \mathrm{sec}^{-1}$ just before the tsunami and shows an anti-cyclonic eddy (clockwise in the northern hemisphere) in the Bay (Fig. 5a), which was due to the seasonal temperature, salinity, river run-off and rainfall. The patterns of geostrophic surface current were irregular just after the tsunami (Fig. 5b) because of the effect of tsunami waves. Abrupt changes in dynamic height, due to the tsunami, are responsible for current patterns. A few weeks after the tsunami, the dynamic heights obtained were back to regular values due to regional temperature, salinity and rainfall and thus showed similar current patterns as before the tsunami.

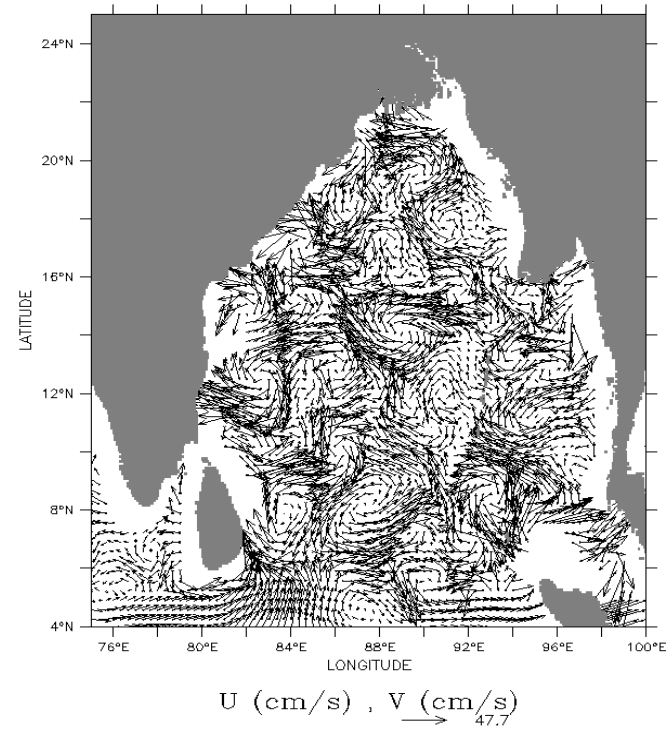

(b)

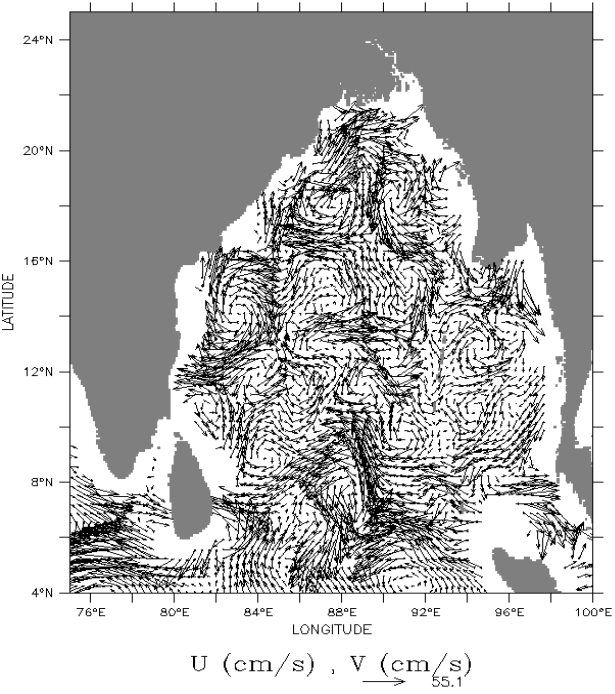

(c)

Fig. 5: Geostrophic surface current in the Bay of Bengal (a) just before, (b) just after and (c) long after the tsunami 
The geostrophic surface currents in Fig. 5 show that the magnitude of the surface currents was around $58 \mathrm{~cm}$ $\mathrm{sec}^{-1}$ near the coasts of the Bay of Bengal. This high surface current near the mouth is due to water entering from the river into the Bay and it changes the dynamic height accordingly. Before the tsunami, the altimetry dynamic heights obtained from the website ${ }^{[15]}$ were quite low (180-200 dym $\mathrm{cm}$ ) as compared to the dynamic height just after the tsunami, which ranged from 200-230 dym cm. Thus, the surface geostrophic current that is calculated from the dynamic height data varied dramatically just after the tsunami with many eddies in the Bay.

Eddies with horizontal diameters varying from 50-150 $\mathrm{km}$ have their own pattern of surface currents. These features may either have a warm or a cold core and currents flow around this core either cyclonically for cold cores or anti-cyclonically for warm cores ${ }^{[10]}$. Vector geostrophic surface current plots in Fig. 5 show an anti-cyclonic eddy in the Bay since it was a winter season (December-January in northern hemisphere) during which the investigation was carried out. Therefore, there was a warm core in the Bay.

Obviously, the sudden change in the surface current was due to the underwater earthquake near Sumarta, which resulted in an increase in the dynamic heights. Thus, huge waves started to build in the deep waters and this water has been carried away from the coast line. Those entire factors affect the sudden change of geostrophic surface current in the region.

As the Bay of Bengal is a part of the northern Indian Ocean, the oceanic circulation is controlled through the seasonally changing monsoon gyre (anticlockwise through the winter monsoon current). The tsunami-induced wave pattern are likely generated by internal waves, modified by interactions with surface waves, which results in change in the surface roughness ${ }^{[9]}$. It remains unclear, both theoretically and observationally, how these internal waves have substantially affected the suspended sediment concentrations at the sea surface and how much these changes have affected the shelf break and continental slope. Thus, a clear understanding of vertical and horizontal mixing and its effect on the sediment transport is needed for future investigations ${ }^{[9]}$.

\section{CONCLUSION}

The variation in the temperature and salinity profile in the Bay are the major cause of the change in the dynamic height, which results in variation in the geostrophic surface current. The sea surface temperature was around $28^{\circ} \mathrm{C}$ before the event and decreased to $26^{\circ} \mathrm{C}$ just after the event (Fig. 2), whereas there was approximately 2 psu change in surface salinity. Before the tsunami the surface salinity in the Bay was in between 33-34 psu, but it decreased to 32 psu just after the tsunami (Fig. 3).

The reference level (level of no motion) in the study area was taken as $1500 \mathrm{~m}$. This was verified by comparing the drift velocity of the ARGO float at its parking depth $(1000 \mathrm{~m})$ with the calculated geostrophic current at this depth. Generally looking at Table 3, the difference between them was approximately $6 \%$ in average speed. This verifies that the reference level of $1500 \mathrm{~m}$ in the Bay of Bengal is appropriate.

This reference level, $1500 \mathrm{~m}$ was than used to calculate the surface geostrophic current in the Bay of Bengal, before and after the tsunami, occurred during Boxing Day of 2004. The surface current before the tsunami shows less eddies in the Bay. But just after the tsunami, there were more eddies with high current in the coastline and the entrance of the Bay in the North. This was due to the decrease in sea surface temperature and salinity in the Bay that leads to an increase in the dynamic height and therefore changes the surface geostrophic current patterns in the Bay.

A point to be noted here is that the waves propagating along with the current direction will have the effect of increasing wave speed and the rate of energy transfer is to remain constant, as speed increase, wave height should decrease. Conversely, if the current flows against the direction of wave propagation, the wave speed slows down and the resultant waves will be higher. Therefore in short, as wave propagate against a counter-current of ever-increasing strength, the waves become steeper and higher until they become unstable and break ${ }^{[20]}$. It could be a major reason some countries like Bangladesh and western part of Burma (Myanmar) had relatively lesser damage than the other countries and areas in the Bay of Bengal due to the tsunami.

\section{REFERENCES}

1. Somaiya, K.J. and V. Vihar, 2006. Effect of 2004 tsunami on marine ecosystem. Sci. Correspondence, 90: 772 - 773. http://www.ias.ac.in/currsci/mar252006/772.pdf

2. Gower, J., 2005. Jason 1 detects the 26 December 2004 Tsunami. EOS, Trans. Am. Geophys. Union, 86: 37-40 Doi: 10.1029/2005EO040002

3. Wikipedia, "2004 Indian Ocean Earthquake," March 2006;

http://en.wikipedia.org/wiki/2004_Indian_Ocean_e arthquake

4. Ram, P.S. and L.V.G. Rao, 2005. Upper Ocean Physical Processes in the Tropical Indian Ocean. $1^{\text {st }}$ Edn.,National Institute of Oceanography, Regional Centre, Visakhapatnam, India, pp: 68. http://drs.nio.org/drs/handle/2264/93 
5. Bhat, G.S., S. Gadgil, P.V.H. Kumar, S.R. Kalsi, P. Madhusoodanan, V.S.N. Murty, C.V.K. Rao, V.R. Babu, L.V.G. Rao, R.R. Rao, M. Ravichandran, K.G. Reddy, P.S. Rao, D. Sengupta, D.R. Sikka, J. Swain and P.N. Vinayachandran, 2001. BOBMEX: The Bay of Bengal monsoon experiment. Bull. Am. Meteorol. Soc., 82: 22172243. http://ams.allenpress.com/archive/15200477/82/ 10/pdf/i1520-0477-82-10-2217.pdf

6. Swain, J., R.K. Shukla, A.R. Rao, J.K. Panigrahi and N.R. Venkitachalam, 2003. Observations of wind and waves in the central Bay of Bengal during BOBMEX-99 and their effect on mixed layer depth variability due to forced mixing. J. Earth Planet Sci., 112: 255-266. Doi: 10.1007/BF02701991

7. Vinayachandran, P.N., V.S.N. Murty and V.R. Babu, 2002. Observations of barrier layer formation in the Bay of Bengal during summer monsoon. J. Geophys. Res., 107: SRF 19-1. Doi: 10.1029/2001JC000831

8. Hamon, B.V., 1965. Geostrophic current in the South-Eastern Indian Ocean. Aust. J. Marine Freshwater Res., 16: 255-271. Doi: 10.1071/MF9650255

9. Santek, D.A. and A. Winguth, 2005. A satellite view of internal waves induced by the Indian Ocean Tsunami. Int. J. Remote Sens., 28, 1-10. http://www.uta.edu/faculty/awinguth/Research/Tsu nami_Internal_Waves.pdf

10. Pond, S. and G.L. Pickard, 1983. Introductory Dynamical Oceanography. 2nd Edn., Pergamon Press, Oxford, pp: 74-99. ISBN-13: 9780750624961

11. Pickard, W.J. and G.L. Emery, 1990. Descriptive Physical Oceanography. 5th Edn., Pergamon Press, New York, pp: 320. ISBN-13: 978-0750627597
12. Fomin, L., 1964. The Dynamic Method in Oceanography. Institute of Oceanography. Academy of Science of the USSR, Moscow, pp: 212. ISBN-13: 978-0444402400

13. Aviso, "Altimetry," April 2006 ; http://www.aviso.oceanobs.com/en/altimetry/index .html

14. Argo Information Centre, "Argo Real Time Status, " March 2006; http://wo.jcommops.org/cgibin/WebObjects/JCOMMOPS.woa/2/wo/akMKKb zMNijn6t6ndbueUw/1.0.24.2.1.2.1.0.0

15. Aviso, "Absolute Dynamic Height," April 2006; http://www.aviso.oceanobs.com/index.php?id=1269

16. Robinson, I.S., 1985. Satellite Oceanography: An Introduction for Oceanographers and Remote Sensing Scientists. $1^{\text {st }}$ Edn., John Wiley and Sons, New York, USA., pp: 455. ISBN-10: 0470201487 ISBN-13: 978-0470201480

17. Geoscience Australia, "Geodetic Calculation," 30th March 2006;

http://www.ga.gov.au/geodesy/datums/vincenty_in verse.jsp

18. Ichikawa, Y., Y. Takatsuki, K. Mizuno, N. Shikama and K. Takeuchi, 2002. Estimation of drifting velocity and error at parking depth for the Argo float. JAMSTECR, 44: 81 - 89.

19. Brown, J., A. Colling, D. Park, J. Phillips, D. Rothery and J. Wright, 1989. Ocean Circulation. $1^{\text {st }}$ Edn., Open University Course Team, Pergamon Press, Oxford, pp: 238. ISBN-10: 0080363709 ISBN-13: 978-0080363707

20. Brown, J., A. Colling, D. Park, J. Phillips, D. Rothery and J. Wright, 1991. Waves, Tides and Shallow-Water Processes. $1^{\text {ST }}$ Edn., Open University, Walton Hall, Milton Keynes, Pergamon Press, Oxford, pp: 31-37. ISBN-10: 0080363725 ISBN-13: 978-0080363721 